\title{
THE EFFECT OF RETINAL AUTOANTIGENS AND THEIR PEPTIDES ON THE INHIBITION OF EXPERIMENTAL AUTOIMMUNE UVEITIS
}

\author{
H. S. DUA, M. S. ABRAMS, J. A. BARRETT, L. A. DONOSO \\ Philadelphia, USA
}

\begin{abstract}
SUMMARY
Experimental autoimmune uveitis is an immunemediated inflammation of the retina and uveal tract. Such inflammation can be induced in eyes of experimental animals by inoculating them with retinal autoantigens. This animal model of uveitis closely resembles idiopathic uveitis in humans and lends itself ideally for the study of mechanisms involved in the aetiopathogenesis of uveitis and for the evaluation of methods used to controt or prevent immune-mediated intraocular inflammation. In this study we used the retinal proteins S-antigen, interphotoreceptor retinoid binding protein and some synthetic peptides of $S$-antigen to modulate the immune response of Lewis rats. Following immunomodulation these animals did not develop uveitis when challenged with the retinal proteins. The discovery of small, non-pathogenic peptides of retinal antigens that downregulate the immune response has relevance in developing strategies for immune intervention in human uveitis.
\end{abstract}

Experimental autoimmune uveitis (EAU) is a cellmediated autoimmune inflammatory disease of the retina and uveal tract of the eye. T-helper cells are principally involved in the initiation and perpetuation of the disease process. Several retinal proteins which normally play important roles in physiological processes within the retina, such as phototransduction of vision and transport of retinoids, are also potential autoantigens. ${ }^{1,2}$ Two of these proteins, namely S-antigen (SAg) and interphotoreceptor retinoid binding protein (IRBP), are very potent in this regard. $^{3-6}$ These proteins have been extensively studied. Their amino acid sequence has been determined and analyses of their smaller fragments or peptides, both in vitro and in vivo, have revealed several different segments or

From: The Retina Service, Research Division, Wills Eye Hospital, Philadelphia, USA.

Correspondence to: H. S. Dua, Research Department, Wills Eye Hospital, 900 Walnut Street, Philadelphia, PA 19107, USA. epitopes that bind to antibodies (antibody-binding epitopes), induce disease (pathogenic epitopes) or stimulate T-lymphocytes to proliferate (proliferative epitopes). ${ }^{7-16}$

The clinical and histopathological features of EAU induced by both of these proteins and by their synthetic pathogenic peptides are very similar and bear a close resemblance to endogenous clinical uveitis in humans. ${ }^{17}$ EAU thus serves as an excellent animal model for clinical uveitis. Considerable information on the immunopathogenesis and pathology of autoimmune uveitis has been obtained using this model. It is now being studied to develop strategies for immune intervention in uveitis, i.e. to induce a state of immune unresponsiveness or tolerance such that the T-lymphocytes are rendered incapable of recognising the retinal antigens and mounting an immunological response.

We attempted to induce tolerance to SAg and IRBP by parenteral administration of very small quantities of these antigens coupled to spleen cells. This method has been shown to be effective in the animal model of experimental allergic encephalomyelitis (EAE), another T-helper lymphocyte mediated autoimmune disorder, induced by myelin basic protein. ${ }^{18,19} \mathrm{We}$ also used this method to test several peptides of SAg in order to find one or more peptides that would successfully prevent the induction of EAU. Synthetic peptides of SAg corresponding to the known 'antibody-binding', 'pathogenic' and 'proliferative' epitopes were coupled to spleen cells and administered to inbred (syngeneic) Lewis rats. The tolerising effect of these peptides against immunisation with the complete molecule of SAg was studied. The results of these studies are presented.

\section{MATERIALS AND METHODS}

Preparation of Retinal Antigens and Synthetic Peptides

Both SAg and IRBP were obtained and purified from 
Table I. Synthetic peptides of SAg used to coat spleen cells

\begin{tabular}{lll}
\hline $\begin{array}{l}\text { Peptide } \\
\text { designation }\end{array}$ & $\begin{array}{c}\text { Amino acid } \\
\text { positions }\end{array}$ & Sequence \\
\hline$\# 649^{\mathrm{a}}$ & $031-051$ & YIDHVRVEPVDGVBVLVDPEL \\
$\# 660^{\mathrm{b}}$ & $143-162$ & CGVDFEIKAFATHSTDVEED \\
$\# 673^{\mathrm{b}}$ & $273-292$ & SLTKTLTLVPLLANNRERRG \\
$\# 674^{\prime} \mathrm{N}^{\mathrm{c}}$ & $283-302$ & LLANNRERRGLLDGKIKHE \\
$\# 676^{\circ} \mathrm{M}^{\mathrm{c}}$ & $303-322$ & DTNLASSTIKEGIDKTVMG \\
$\# 926^{\mathrm{b}}$ & $317-328$ & DKTVMGILVSYQ \\
$\# 679^{\mathrm{b}}$ & $333-352$ & LTVSGLLGELTSSEVATEVP \\
$\# 680^{\mathrm{c}}$ & $343-362$ & TSSEVATEVPFRLMHPQPED \\
$\# 61^{\mathrm{a}}$ & $353-372$ & FRLMHPQPEDPDTAKESF \\
$\# 683^{\mathrm{a}}$ & $373-392$ & ENFVFEEFARQNLKDAGEYK \\
$\# 684^{\mathrm{a}}$ & $383-404$ & QNLKDAGEYKEEKTDQEAAMDE \\
\hline
\end{tabular}

${ }^{a}$ Antibody-binding peptides; ${ }^{\mathrm{b}}$ proliferative peptides; ${ }^{\mathrm{c}}$ pathogenic peptides.

Underlined portions of peptides ' $\mathrm{M}$ ', ' $\mathrm{N}$ ' and \#681 also bind to anti-SAg monoclonal antibodies MAbH11A2, MAbC10C10 and MAbA2G5 respectively.

bovine eyes. SAg was prepared by the method of Wacker and associates ${ }^{20}$ by Sephadex and phenyl sepharose chromatography. IRBP was prepared by the method of Fong et $a l .{ }^{21}$ Eleven peptides of SAg as illustrated in Table I, corresponding to its known 'antibody-binding', 'pathogenic' and 'proliferative' epitopes were synthesised by conventional solid phase techniques as described before. ${ }^{12}$

\section{Coupling of SAg, Peptides and IRBP to Spleen Cells}

One hundred and eleven female Lewis rats, 6-8 weeks old, were used in this experiment. Erythrocyte-free spleen cell suspensions were obtained from inbred (syngeneic) animals, washed in phosphate-buffered saline and mixed with $500 \mathrm{mg} / \mathrm{ml}$ solution of SAg, synthetic peptides or IRBP; or with saline without any protein (sham coating for controls). A freshly made solution of ethyl-dimethyl-aminopropyl-carbodiimide (ECDI) $100 \mathrm{mg} / \mathrm{ml}$ was used chemically to couple the antigens or peptides to spleen cells. After thorough washing the cells were resuspended in a final concentration of $1 \times 10^{8}$ cells in $0.2 \mathrm{ml}$ saline. Each animal received $0.2 \mathrm{ml}$ of the coated or sham coated cells intravenously in the tail vein, under ketamine anaesthesia. Five days later the animals were immunised with antigen and adjuvants as indicated in Tables II-V.

\section{Clinicopathological Assessment of EAU}

One week following immunisation the rats were observed daily for development of EAU by slit lamp biomicroscopy. The appearance of uveitis was noted and graded on a scale of 0 to 4 . Serum samples from all animals were obtained prior to immunisation and on day 21 post-immunisation. These were tested for the presence of anti-SAg or antiIRBP antibodies by the enzyme-linked immunosorbent assay (ELISA). ${ }^{22}$ Animals were killed on day 21 postimmunisation. The eyes removed, fixed in formalin and examined histologically.

\section{RESULTS}

\section{Inhibition of SAg-and IRBP-Induced EAU}

Both retinal proteins, SAg and IRBP, when coupled to spleen cells and administered intravenously, successfully induced a state of tolerance in animals. These animals showed minimal clinical and histological changes of uveitis (Table II). Clinically the onset of uveitis was delayed and severity was mild. Histopathologically, uveal inflammation was manifest as a few scattered vitreous cells and some perivascular infiltration of the retinal vessels. The photoreceptor layer was notably intact in all animals (Fig. 1a). The tolerance was very specific for the antigen used. Neither of the proteins afforded cross protection against immunisation with the other protein (Fig. 1b). All control animals showed severe clinical and histopathological uveitis.

\section{Antibody Responses}

The anti-SAg and anti-IRBP antibody activity observed in serum samples of the animals is shown in Fig. 2. The antibody response was predominantly against the antigen used to challenge the animals, irrespective of the antigen

Table II. Clinical and histological uveitis in animals receiving spleen cells coated with SAg and IRBP

\begin{tabular}{|c|c|c|c|c|c|c|c|}
\hline \multirow{2}{*}{$\begin{array}{l}\text { Antigen coupled } \\
\text { to spleen cells }\end{array}$} & \multirow{2}{*}{$\begin{array}{l}\text { No. of } \\
\text { animals }\end{array}$} & \multirow{2}{*}{$\begin{array}{l}\text { Immunising }^{\mathrm{a}} \\
\text { antigen/dose }\end{array}$} & \multicolumn{2}{|c|}{ Clinical uveitis } & \multirow{2}{*}{$\begin{array}{c}\text { Day of } \\
\text { onset }\end{array}$} & \multicolumn{2}{|c|}{ Histological uveitis } \\
\hline & & & Number & Grade & & Number & Grade \\
\hline SAg & 4 & IRBP $50 \mu \mathrm{g}$ & 4 & ++++ & 11 & 4 & ++++ \\
\hline IRBP & 4 & IRBP $50 \mu \mathrm{g}$ & 0 & - & - & 4 & + \\
\hline IRBP & 4 & SAg $50 \mu \mathrm{g}$ & 4 & ++++ & 14 & 4 & ++++ \\
\hline Sham coated & 5 & SAg $50 \mu \mathrm{g}$ & 5 & +++ & 14 & 5 & ++++ \\
\hline Sham coated & 4 & IRBP $50 \mu \mathrm{g}$ & 4 & ++++ & 10 & 4 & ++++ \\
\hline
\end{tabular}

${ }^{\text {a }}$ Antigen was emulsified in complete Freund's adjuvant (H37 Ra, Difco Laboratories, Detroit, MI) and administered by foot pad injection. Animals also received $10^{10}$ cells of Bordetella pertussis in $1 \mathrm{ml}$ saline, intraperitoneally. 


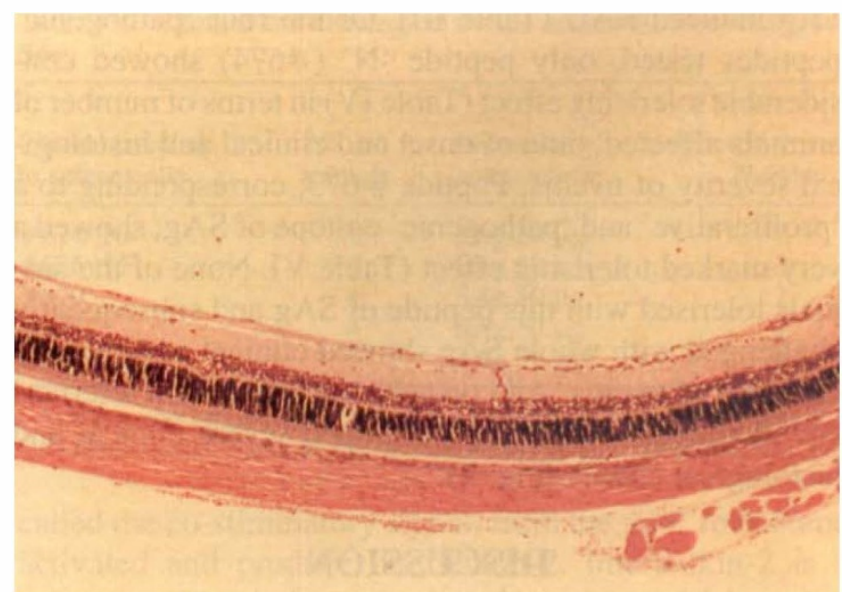

Fig. 1a.

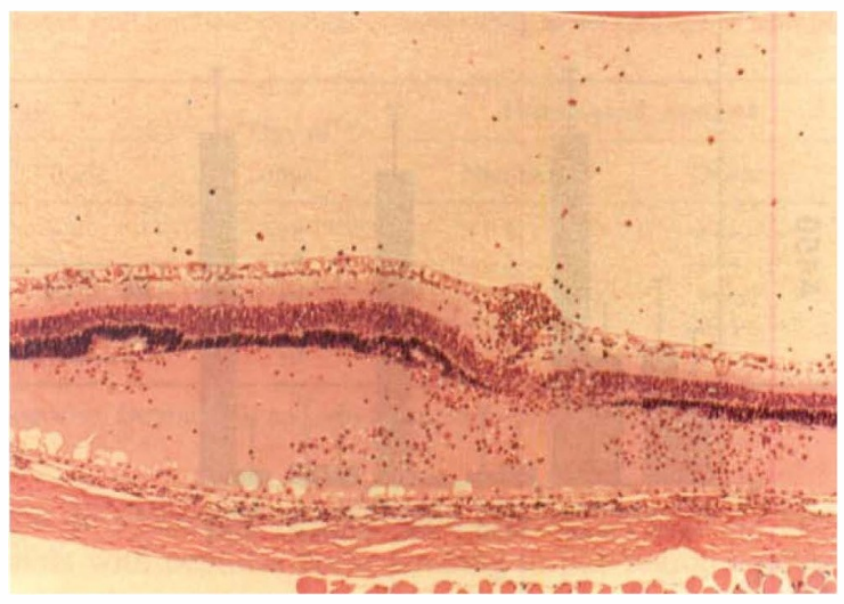

Fig. 1b.

Fig. 1. (a) Isolated inflammatory cells in vitreous and inner retinal layers in the eye of an animal given ECDI-treated, SAg-coated spleen cells and challenged 5 days later with SAg. The retinal architecture and photoreceptor layer are preserved. The choroid does not show any inflammatory cell infiltration. Haematoxylin and esoin $(H \& E) \times 85$, day 21 post-challenge. (b) Photomicrograph of the eye of a rat given ECDI-treated, SAg-coated spleen cells and challenged 5 days later with IRBP. The choroid is infiltrated with inflammatory cells. There is a complete loss of photoreceptors with patchy loss of the inner nuclear layer, a large subretinal exudate, perivasculitis and inflammatory cells in the vitreous. Grade 4 EAU. $H \& E \times 85$, day 21 post-challenge.

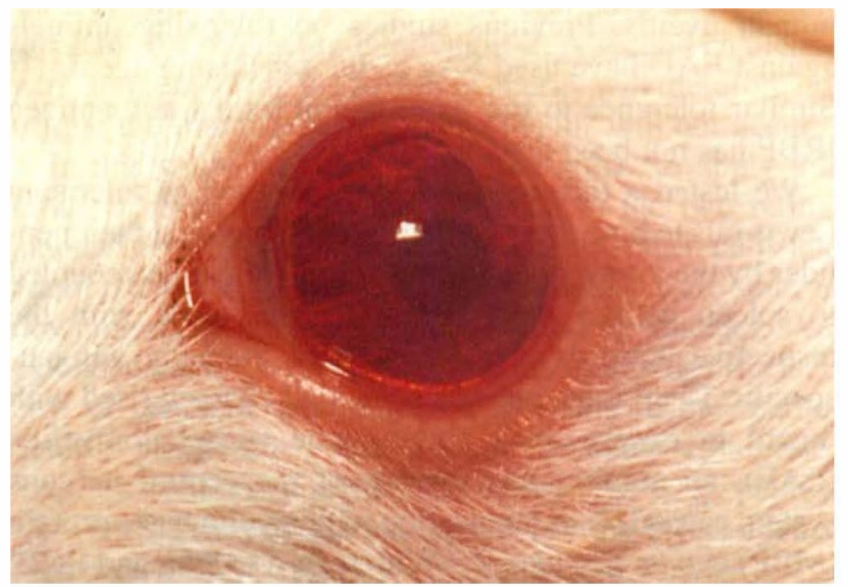

Fig. 3a.

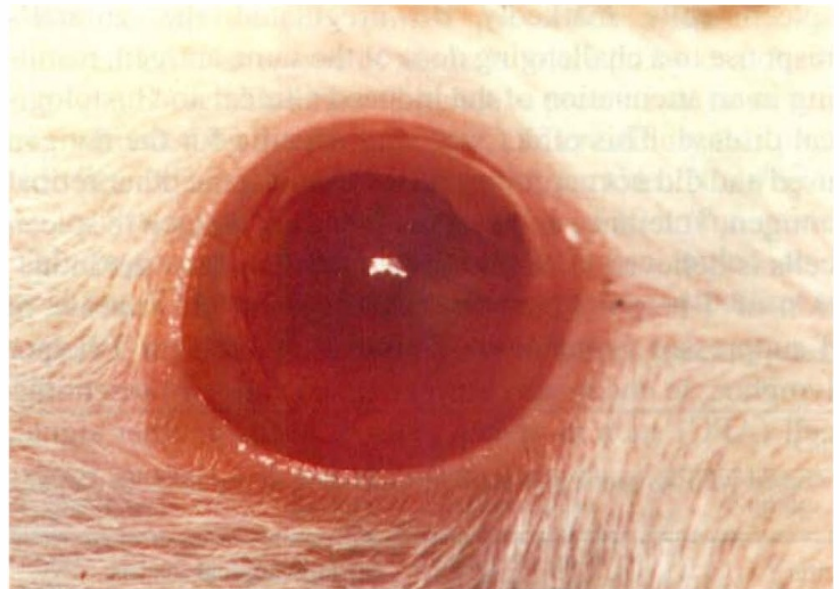

Fig. 3c.

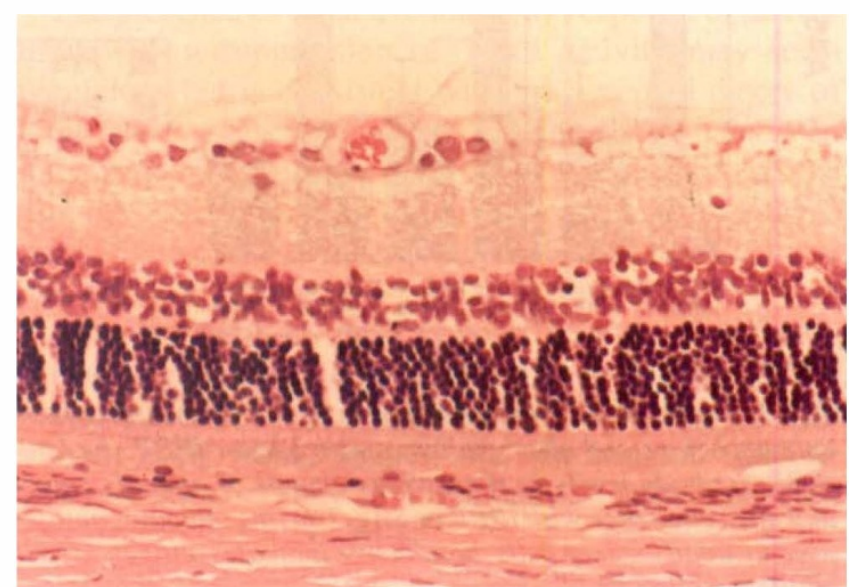

Fig. 3b.

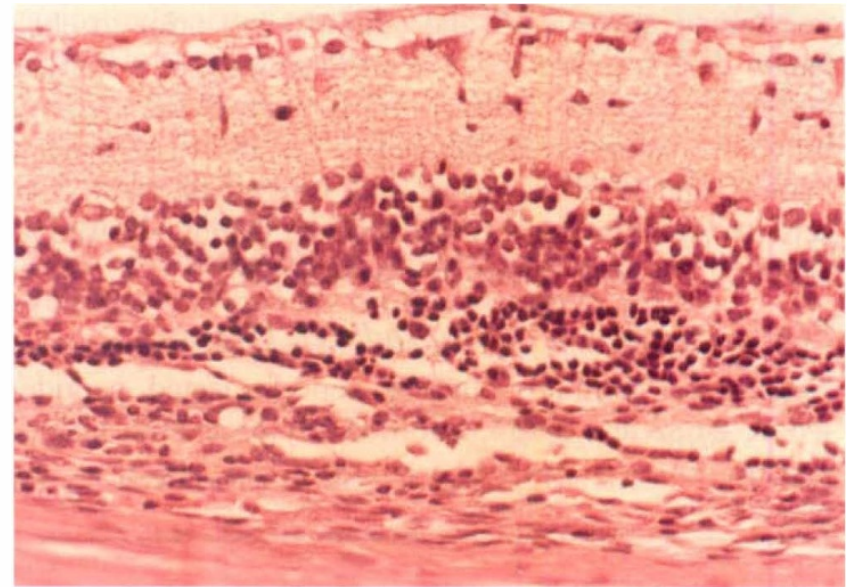

Fig. 3d.

Fig. 3. (a) Clinical photograph of eye of rat given ECDI-treated, peptide \#673-coated spleen cells and challenged 5 days later with SAg. Grade 0 clinical EAU. (b) Photomicrograph of same eye showing normal retina with a well-preserved photoreceptor layer. Grade 0 EAU. $H \& E \times 350$, day 21 post-challenge. (c) Clinical photograph of eye of control rat given ECDI-treated sham coated spleen cells and challenged 5 days later with SAg. The cornea is cloudy, iris vessels are congested, there is exudate in the pupillary area with a large hypopyon. Grade 4 clinical EAU. Photograph was taken on day 15 post-challenge. (d) Photomicrograph of same eye showing complete destruction of the retinal architecture. There is a complete absence of photoreceptors and their nuclei are reduced to a thin layer. Grade 4 EAU. H\&E $\times 350$, day 21 post-challenge. 


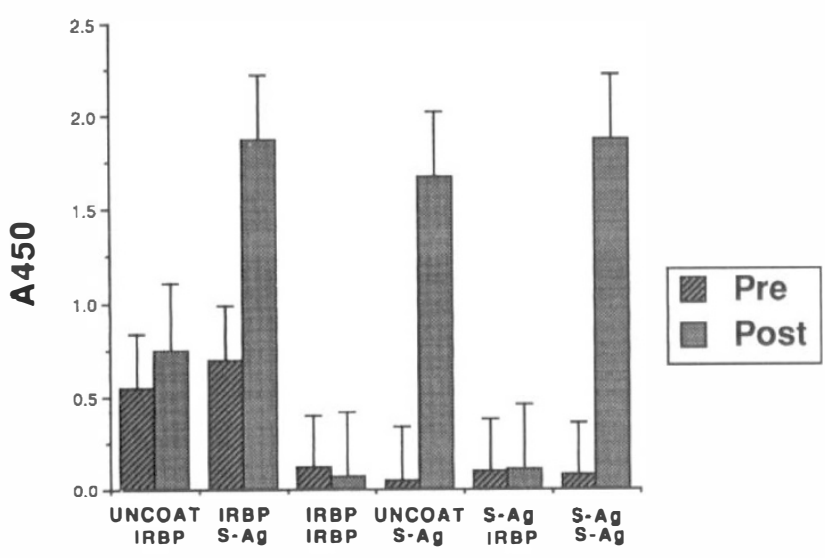

Fig. 2a.

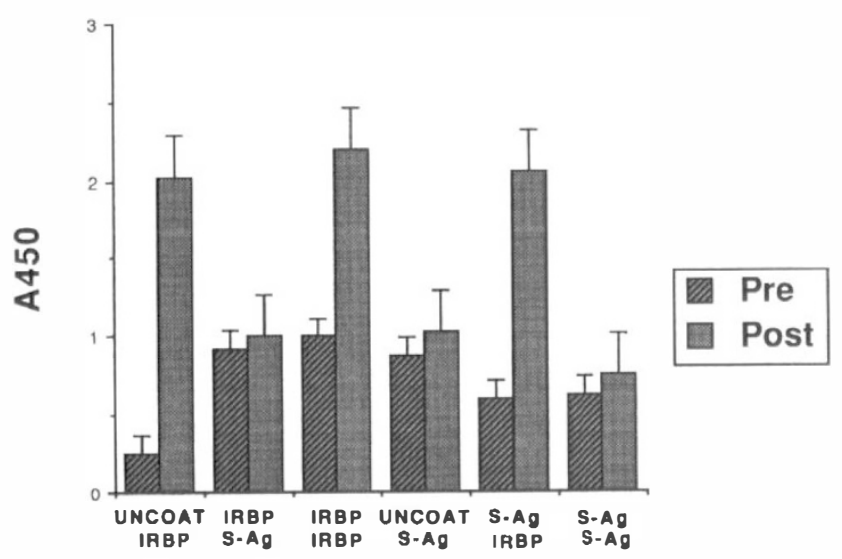

Fig. 2b.

Fig. 2. (a) Anti-SAg antibody levels in the various groups of animals before and after challenge with SAg or IRBP. (b) AntiIRBP antibody levels in the various groups of animals before and after challenge with IRBP or SAg.Top line indicates antigen used to modify spleen cells, bottom line indicates antigen used to challenge animals.

coupled to spleen cells and administered prior to challenge. Animals challenged with SAg showed a marked anti-SAg response with minimal anti-IRBP activity. Similarly, animals challenged with IRBP showed a marked anti-IRBP response and insignificant anti-SAg activity. All animals, with and without uveitis, showed an antibody response to one or other antigen.

\section{Peptide Inhibition of SAg-Induced Uveitis}

None of the 'antibody-binding' peptides tested, peptides \#649, \#683 and \#684, afforded any protection against
SAg-induced EAU (Table III). Of the four 'pathogenic' peptides tested, only peptide ' $N$ ' (\#674) showed considerable tolerising effect (Table IV) in terms of number of animals affected, time of onset and clinical and histological severity of uveitis. Peptide \#673, corresponding to a 'proliferative' and 'pathogenic' epitope of SAg, showed a very marked tolerising effect (Table V). None of the animals tolerised with this peptide of SAg and subsequently challenged with whole SAg showed clinical or histological signs of uveitis. All controls that were sham tolerised and challenged with SAg developed severe clinical and histological uveitis (Fig. 3).

\section{DISCUSSION}

The entire range of clinical and pathological changes that occur in chronic endogenous uveitis in humans can be reproduced in animals following immunisation with retinal SAg and IRBP. ${ }^{17}$ The ability to downregulate the host's immune response and an understanding of the mechanisms involved in such immunomodulation will help us develop protocols for immune intervention in human uveitis. Previous studies on tolerising animals against EAU have used SAg as the sensitising agent. ${ }^{22-25}$ Similar tolerance to the more potent retinal autoantigen IRBP has not been described.

We tested a different and novel method of tolerising Lewis rats to both these retinal autoantigens and their peptides by the intravenous administration of antigen coupled to spleen cells 5 days before immunisation with the respective antigens. This method of inducing antigenspecific T-cell tolerance has been well characterised with regard to experimental autoimmune encephalomyelitis (EAE), an autoimmune disease of the central nervous system caused by immunisation with myelin basic protein (MBP) and its peptides. ${ }^{18,19}$ With regard to SAg and IRBP we demonstrated that the administration of antigen-coated spleen cells markedly downregulated the animal's response to a challenging dose of the same antigen, resulting in an attenuation of the induced clinical and histological disease. This effect was very specific for the antigen used and did not confer protection against the other retinal antigen. Tolerance achieved by coupling antigen to spleen cells is believed to occur via two mechanisms: the induction of T-helper lymphocyte anergy and an increase in T-suppressor lymphocyte activity. ${ }^{26-29}$ When a T-helper lymphocyte encounters antigen on an antigen-presentingcell (APC) such as spleen cells, it needs another signal,

Table III. Clinical and histological uveitis in animals receiving spleen cells coated with synthetic peptides corresponding to the antibody-binding sites of SAg

\begin{tabular}{|c|c|c|c|c|c|c|c|}
\hline \multirow{2}{*}{$\begin{array}{l}\text { Antigen coupled } \\
\text { to spleen cells }\end{array}$} & \multirow{2}{*}{$\begin{array}{l}\text { No. of } \\
\text { animals }\end{array}$} & \multirow{2}{*}{$\begin{array}{l}\text { Immunising }^{\mathrm{a}} \\
\text { antigen/dose }\end{array}$} & \multicolumn{2}{|c|}{ Clinical uveitis } & \multirow{2}{*}{$\begin{array}{c}\text { Day of } \\
\text { onset }\end{array}$} & \multicolumn{2}{|c|}{ Histological uveitis } \\
\hline & & & Number & Grade & & Number & Grade \\
\hline \#649 & 5 & SAg $50 \mu \mathrm{g}$ & 5 & +++ & 14 & 5 & ++++ \\
\hline \#683 & 5 & SAg $50 \mu \mathrm{g}$ & 5 & ++++ & 12 & 5 & ++++ \\
\hline \#684 & 5 & SAg $50 \mu \mathrm{g}$ & 5 & ++++ & 12 & 5 & ++++ \\
\hline Sham coated & 5 & SAg $50 \mu \mathrm{g}$ & 5 & ++++ & 13 & 5 & ++++ \\
\hline
\end{tabular}

${ }^{a}$ Antigen was emulsified in complete Freund's adjuvant (H37 Ra, Difco Laboratories, Detroit, MI) and administered by foot pad injection. Animals also received $10^{10}$ cells of Bordetella pertussis in $1 \mathrm{ml}$ saline, intraperitoneally. 
Table IV. Clinical and histological uveitis in animals receiving spleen cells coated with synthetic peptides corresponding to the pathogenic sites of SAg

\begin{tabular}{|c|c|c|c|c|c|c|c|}
\hline \multirow{2}{*}{$\begin{array}{l}\text { Peptide coupled } \\
\text { to spleen cells }\end{array}$} & \multirow{2}{*}{$\begin{array}{l}\text { No. of } \\
\text { animals }\end{array}$} & \multirow{2}{*}{$\begin{array}{l}\text { Immunising } \\
\text { antigen/dose }\end{array}$} & \multicolumn{2}{|c|}{ Clinical uveitis } & \multirow{2}{*}{$\begin{array}{c}\text { Day of } \\
\text { onset }\end{array}$} & \multicolumn{2}{|c|}{ Histological uveitis } \\
\hline & & & Number & Grade & & Number & Grade \\
\hline \#674 'N' & 11 & $\mathrm{SAg} 50 \mu \mathrm{g}$ & 3 & ++ & 18 & 4 & +++ \\
\hline \#676 'M' & 5 & $\mathrm{SAg} 50 \mu \mathrm{g}$ & 3 & +++ & 15 & 3 & +++ \\
\hline \#679 & 4 & $\mathrm{SAg} 50 \mu \mathrm{g}$ & 2 & ++ & 14 & 2 & +++ \\
\hline \#680 & 4 & SAg $50 \mu \mathrm{g}$ & 2 & ++ & 14 & 2 & +++ \\
\hline Sham coated & 5 & $\mathrm{SAg} 50 \mu \mathrm{g}$ & 4 & ++++ & 14 & 4 & ++++ \\
\hline
\end{tabular}

${ }^{a}$ Antigen was emulsified in complete Freund's adjuvant (H37 Ra, Difco Laboratories, Detroit, MI) and administered by foot pad injection. Animals also received $10^{10}$ cells of Bordetella pertussis in $1 \mathrm{ml}$ saline, intraperitoneally.

called the co-stimulatory signal, from the APC to become activated and produce interleukin-2. Interleukin-2 is a substance (lymphokine) produced by activated T-lymphocytes. This is required for the recruitment of other cells of the cell-mediated immune response. However, when antigen is presented but the co-stimulatory signal is lacking from the APC, as is the case with spleen cells coated with antigen but chemically treated with ECDI, instead of becoming activated, the T-helper lymphocytes pass into a state of anergy for a period of several days and become incapable of producing interleukin-2. A second challenge with antigen during the period of anergy will therefore not trigger the immune response and uveitis will not occur.

In this study we were able successfully to apply this mode of inducing immune tolerance to the two retinal autoantigens SAg and IRBP. Coupled to spleen cells and administered to Lewis rats, both antigens were able to downregulate EAU in a very specific manner. We extended our experiments to study the tolerising effects, if any, of synthetic peptides corresponding to the 'pathogenic', 'proliferative' and 'antibody-binding' epitopes of $\mathrm{SAg}$. Of the known pathogenic epitopes of SAg, peptide ' $N$ ' (\#674) showed the maximal tolerising effect against induction of EAU following immunisation with SAg. The other pathogenic peptides, peptide ' $M$ ' (\#676), \#679 and \#680, conferred only partial protection against SAginduced EAU as is true of animals tolerised by oral feeding with $\mathrm{SAg} .{ }^{23} \mathrm{The}$ most conclusive protection, however, was afforded by the peptide \#673. Interestingly this peptide lies adjacent to the 'pathogenic' peptide ' $N$ ' (\#674) on its $\mathrm{N}$-terminus side with an overlap of 10 amino acids. This region of the SAg molecule between amino acid positions 273 and 302 therefore appears to be important in the development of SAg-induced EAU. Tolerising animals with peptides corresponding to this region confers protection against subsequent immunisations with the complete SAg molecule and is similar to the protection afforded by tolerising animals with the complete $\mathrm{SAg}$ molecule. These results would indicate that the region between amino acids 273 and 302 is the immunodominant region relative to the regions corresponding to other peptides studied.

The presence of an active antibody response in association with a suppression of T-cell activity may seem anomalous but is consistent with the accepted theory of T-cell anergy described above. Binding of antigen to an antigen-specific receptor on the T-lymphocyte in the absence of a co-stimulatory signal is sufficient stimulus to induce the cell to produce the lymphokine interleukin- 4 (IL4). IL4 in turn helps B-cells to secrete antibody . This would allow antibody production in the absence of T-cellmediated pathogenic effects as shown in our study. The marked antibody response shown by all animals with and without EAU would suggest that the humoral immune response does not play an important role in the induction of tolerance to SAg or IRBP.

This study has shown that retinal autoantigens coupled to spleen cells can be used successfully to induce tolerance against retinal antigen-induced EAU. This is an effective method of inducing tolerance in which the dose of the tolerising antigen required is small and can be administered in a controlled manner. Our study has also revealed an immunodominant region of SAg corresponding to peptides \#673 and \#674 (positions 273-302). The discovery of an immunodominant region will have relevance in evolving strategies for peptide therapy of EAU.

Table V. Clinical and histological uveitis in animals receiving spleen cells coated with synthetic peptides corresponding to the proliferative sites of SAg

\begin{tabular}{|c|c|c|c|c|c|c|c|}
\hline \multirow{2}{*}{$\begin{array}{l}\text { Peptide coupled } \\
\text { to spleen cells }\end{array}$} & \multirow{2}{*}{$\begin{array}{l}\text { No. of } \\
\text { animals }\end{array}$} & \multirow{2}{*}{$\begin{array}{l}\text { Immunising }{ }^{\mathrm{a}} \\
\text { antigen/dose }\end{array}$} & \multicolumn{2}{|c|}{ Clinical uveitis } & \multirow{2}{*}{$\begin{array}{c}\text { Day of } \\
\text { onset }\end{array}$} & \multicolumn{2}{|c|}{ Histological uveitis } \\
\hline & & & Number & Grade & & Number & Grade \\
\hline \#660 & 10 & $\mathrm{SAg} 50 \mu \mathrm{g}$ & 6 & +++ & 16 & 6 & +++ \\
\hline \#673 & 6 & $\mathrm{SAg} 50 \mu \mathrm{g}$ & 0 & - & - & - & - \\
\hline$\# 926$ & 5 & $\mathrm{SAg} 50 \mu \mathrm{g}$ & 4 & +++ & 14 & 4 & +++ \\
\hline \# 681 & 5 & $\mathrm{SAg} 50 \mu \mathrm{g}$ & 5 & +++ & 13 & 5 & +++ \\
\hline Sham coated & 5 & SAg $50 \mu \mathrm{g}$ & 5 & ++++ & 13 & 5 & ++++ \\
\hline
\end{tabular}

a Antigen was emulsified in complete Freund's adjuvant (H37 Ra, Difco Laboratories, Detroit, MI) and administered by foot pad injection. Animals also received $10^{10}$ cells of Bordetella pertussis in $1 \mathrm{ml}$ saline, intraperitoneally.

${ }^{b}$ Peptide \#673 is a 'pathogenic' peptide. 
This work was supported in part by the Retina Service of Wills Eye Hospital, National Institutes of Health grants EY5095 and BRSG5510, the Pennsylvania Lions Sight Conservation and Eye Research Foundation, Research to Prevent Blindness Inc., the Crippled Children's Vitreo Retinal Research Foundation (David Meyer, MD, Director), the Elizabeth C. King Trust and the Grampian Health Board, Aberdeen, Scotland (H.S. Dua).

Key words: Autoimmune uveitis, Interphotoreceptor retinoid binding protein (IRBP), Peptides, S-antigen, Tolerance.

\section{REFERENCES}

1. Faure JP: Autoimmunity and the retina. Curr Top Eye Res 1980, 2: 215-301.

2. Gery I, Mochizuki M, Nussenblatt R: Retinal specific antigens and the immunopathogenic processes they provoke. Prog Ret Res 1986, 5: 75-109.

3. De Kozak Y, Sakai J, Thillaye B, Faure JP: S-antigen induced experimental autoimmune uveoretinitis in rats. Curr Eye Res 1981, 1: 327-40.

4. Fox GM, Kuwabara T, Wiggert B, Redmond TM, Hess HH, Chader GJ, Gery I: EAU induced by IRBP: difference between EAU induced by IRBP and S-antigen. Clin Immunol Immunopathol 1987, 43: 256-64.

5. Donoso LA, Merryman CF, Sery T, Sanders R, Vrabec T, Fong SL: Human interstitial retinoid binding protein. A potent uveitopathogenic agent for the induction of experimental autoimmune uveitis. J Immunol 1989, 143: 79-83.

6. Kalsow CM, Wacker WB: Rabbit ocular and pineal autoimmune response to retinal antigens. Curr Eye Res 1986, 5: 579-585.

7. Si JS, Borst DE, Redmond TM, Nickerson JM: Cloning of cDNAs encoding human interphotoreceptor retinoid binding protein (IRBP) and comparison with bovine IRBP sequences. Gene 1989, 80: 99-109.

8. Shinohara T, Dietzschold B, Donoso LA, Howitz J, Tao R: A primary and secondary structure of bovine retinal S-antigen (48Kd protein). Proc Natl Acad Sci USA 1987, 84: 6975-9.

9. Donoso LA, Merryman CF, Shinohara T, Dietzschold B, Wistow G, Craft C, et al.: S-antigen: identification of the MAbA9-C6 monoclonal antibody binding site and the uveitopathogenic sites. Curr Eye Res 1986, 5: 996-1003.

10. Knospe V, Gregerson DS, Donoso LA: Identification of the main immunogenic region of retinal S-antigen: subordinate influence of MHC, IGH, species or strain differences on the specificity of the antibody response. Autoimmunity 1989, 4: 153-69.

11. Knospe V, Donoso LA, Banga JP, Yue S, Kasp E, Gregerson DS: Epitope mapping of bovine retinal S-antigen with monoclonal antibodies. Curr Eye Res 1988, 7: 1137-47.

12. Donoso LA, Merryman CF, Sery TW, Shinohara T, Dietzschold B, Smith A, Kalsow CM: S-antigen: characterisation of a pathogenic epitope which mediates experimental autoimmune uveitis and pinealitis in Lewis rats. Curr Eye Res 1987, 6: 1151-59.

13. Gregerson DS, Fling SP, Obritsch WF, Merryman, Donoso LA: Identification of T-cell recognition sites in S-antigen: Dissociation of proliferative and pathogenic sites. Cell Immunol 1989, 123: 427-40.

14. Gregerson DS, Merryman CF, Obritsch WF, Donoso LA: Identification of a potent new pathogenic site in human ret- inal S-antigen which induces EAU in Lewis rats. Cell Immunol 1990, 128: 209-19.

15. Donoso LA, Merryman CF, Sery TW, Vrabec T, Arbizo V, Fong SL: Human IRBP: characterisation of uveitopathogenic sites. Curr Eye Res 1988, 7: 1087-95.

16. Donoso LA, Gregerson DS, Fling SP, Merryman CF, Sery TW: The use of synthetic peptides in the study of experimental autoimmune uveitis. Curr Eye Res 1990, 9 (Suppl): 155-61.

17. Forrester JV, Liversidge J, Dua HS, Towler H, McMenamin PG: Comparison of clinical and experimental uveitis. Curr Eye Res 1990, 9 (Suppl): 75-84.

18. Kennedy MK, Tan LJ, Dal Canto MC, Tuohy VK, Lu A, Trotter JL, Miller SD: Inhibition of murine relapsing experimental autoimmune encephalomyelitis by immune tolerance to proteolipid protein and its encephalitogenic peptides. J Immunol 1990, 144: 909-15.

19. Kennedy MK, Dal Canto MC, Trotter JL, Miller SD: Specific immune regulation of chronic-relapsing experimental allergic encephalomyelitis in mice. J Immunol 1988, 141: 2986-93.

20. Wacker WB, Donoso LA, Kalsow CM, Yankeelov JA, Organisciak DT: Experimental allergic uveitis. Isolation, characterisation and localisation of a soluble uveitopathogenic antigen from bovine retina. J Immunol 1977, 119: 1949-58.

21. Fong SL, Liou GI, Bridges CDB: Purification of interstitial retinol binding protein from the eye. Methods Enzymol 1986, 123: 102-11.

22. Dua HS, Sewell HF, Forrester JV: The effect of retinal S-antigen-specific monoclonal antibody therapy on experimental autoimmune uveoretinitis and experimental autoimmune pinealitis. Clin Exp Immunol 1989, 75: 100-5.

23. Nussenblatt RB, Caspi RR, Mahdi R, Chan CC, Roberge F, Lider $\mathrm{O}$, Weiner $\mathrm{HL}$ : Inhibition of $\mathrm{S}$-antigen-induced experimental autoimmune uveoretinitis by oral induction of tolerance with S-antigen. J Immunol 1990, 144: 1689-95.

24. Higuchi M, Nussenblatt RB, Diamantstein T, Osawa $H$, Caspi RR. Combined anti-interleukin-2 receptor and lowdose cyclosporin therapy in experimental autoimmune uveoretinitis. Invest Ophthamol Vis Sci 1989, 30 (Suppl): 85.

25. Wetzig R, Hooks JJ, Percopo CM, Nussenblatt RB: Anti Ia antibody diminishes ocular inflammation in experimental autoimmune uveitis. Curr Eye Res 1988, 7: 809-18.

26. Miller SD, Claman HN: The induction of hapten-specific T-cell tolerance by using hapten-modified lymphoid cells. $J$ Immunol 1976, 117: 1519-25.

27. Miller SD, Sy MS, Claman HN: The induction of haptenspecific $\mathrm{T}$ cell tolerance using hapten-modified lymphoid membranes. II. Relative roles of suppressor $\mathrm{T}$ cells and clone inhibition in the tolerant state. Eur J Immunol 1977, 7: $165-9$.

28. Miller SD, Wetzig RP, Claman HN: The induction of cellmediated immunity and tolerance with protein antigens coupled to syngeneic lymphoid cells. J Exp Med 1979, 149: 758-73.

29. Jenkins MC, Schwartz RH: Antigen presentation by chemically modified splenocytes induces antigen-specific T-cell unresponsiveness in vitro and in vivo. J Exp Med 1987, 165: 302-19. 